\title{
Adherence of Pseudomonas aeruginosa to respiratory epithelium and the effect of leucocyte elastase
}

\author{
M. C. PLOTKOWSKI*，G. BECK $\dagger$, J. M. TOURNIERT, M. BERNARDO-FILHO, E. A. MARQUES \\ and E.PUCHELLE‡
}

Serviço de Microbiologia e Immunologia, UERJ, Rio de Janeiro, Brazil, †INSERM U 14, 54511 Vandoeuvreles-Nancy, France and $\ddagger$ INSERM U 314, 51092 Reims, France

\begin{abstract}
Summary. The tracheobronchial secretions from patients with cystic fibrosis often contain high amounts of free proteases. To evaluate whether human leucocyte elastase (HLE) can favour the persistence of bacterial airways infection, we exposed the frog palate mucosa to HLE and then to radiolabelled Pseudomonas aeruginosa and followed the sequence of events by scanning electronmicroscopy. In response to HLE there was a marked outpouring of mucus and a desquamation of the epithelium. $P$. aeruginosa was shown to adhere to recently secreted granules of mucus and to the exposed submucosal underlying connective tissues. For the eight different bacterial strains studied, a significative adherence to HLE-injured mucosa was observed only in strains that possessed internal haemagglutinating activity. Neither the presence of fimbriae, nor of the mucoid exopolysaccharide, nor of the bacterial surface haemagglutinating activity could be related to adherence of $P$. aeruginosa to the injured mucosa. These results support the hypothesis that HLE enhances bacterial infection of the respiratory mucosa both by inducing mucus hypersecretion and by exposing receptors to the microbial adhesins. It is also suggested that $\boldsymbol{P}$. aeruginosa internal lectins may be implicated in adherence to host tissues.
\end{abstract}

\section{Introduction}

Infection of the tracheobronchial mucosa by Pseudomonas aeruginosa represents a major clinical problem in patients with chronic obstructive lung disorders, especially in cystic fibrosis (CF). In these patients, once colonisation is established, bacteria are virtually impossible to eradicate, despite the host immune response to bacterial antigens or antibiotic therapy (Geddes, 1984). P. aeruginosa, however, rarely infects healthy individuals; infection is usually restricted to hospitalised patients or to subjects who have some abnormality of the natural barriers that protect tissues against microbial invasion (Bodey et al., 1983). Since available evidence indicates that the respiratory tract of $\mathrm{CF}$ patients may not be damaged initially (Sturgess, 1981), there must be some factor unique to the CF airway mucosa that allows colonisation by $P$. aeruginosa. It may be that Staphylococcus aureus

Received 4 May 1989; revised version accepted 26 June 1989. *Address to which correspondence should be sent: Dr M. C. Plotkowski, INSERM U 314, 45, Rue Cognacq-Jay, 51092 Reims Cédex, France. infection, detected early in the course of the disease (Pennington et al., 1979), creates local conditions favouring the adherence of $P$. aeruginosa.

Neutrophil polymorphonuclear leucocytes readily accumulate in lung tissue in response to inflammatory processes (Cohen and Rossi, 1983). During phagocytosis (Ohlsson and Olsson, 1977), leucocyte enzymes may be released extracellularly. This degranulation is known to be an important event in the amplification of the inflammatory response (Gallin, 1984). However, the presence of free leucocyte proteolytic enzymes in bronchial secretions, indicative of a local imbalance between proteases and the anti-protease system, may damage host tissues. The spectrum of the human leucocyte elastase (HLE) substrates includes structural proteins such as collagen and elastin, and macromolecules such as proteoglycans (Havemann and Gramse, 1984). Fibronectin, a glycoprotein present in extracellular matrix and at the surface of epithelial cells, is also hydrolysed by HLE (McDonald et al., 1979; Suter et al., 1988). The proteolytic activity of saliva from severely ill patients has been shown to be significantly correlated with the increased adherence of $P$. aeruginosa 
to buccal cells in vitro, due to fibronectin degradation (Woods et al., 1980a, 1983).

The respiratory secretions of chronic bronchitic (CB) and CF patients often contain high amounts of free neutral proteases (Stockley and Burnett, 1979; Suter et al., 1984; Goldstein and Döring, 1986). Besides structural protein degradation, leucocyte proteases are known to stimulate mucus secretion and to damage ciliated cells (Smallman et al., 1984; Kim et al., 1987), two factors known to compromise the transport of tracheobronchial secretions and to favour microbial colonisation of the airways mucosa. Despite all this evidence pointing to a role for HLE in favouring microbial persistence, there has been no systemic study on the effect of HLE on the adherence of $P$. aeruginosa to the respiratory epithelium.

The adherence of $P$. aeruginosa is a very complex phenomenon. The alginate-like exopolysaccharide produced by the majority of the isolates from $\mathrm{CF}$ patients has been imputed to be the bacterial adhesin allowing adherence of mucoid strains of $P$. aeruginosa to both respiratory mucins (Ramphal et al., 1987) and epithelium (Marcus and Baker, 1985; Ramphal and Pier, 1985; Doig et al., 1987). However, infection by non-mucoid micro-organisms often precedes the emergence of mucoid strains, suggesting the role of some other adhesin in bacteria-host mucosa interaction. Several studies have pointed to the fimbriae as the structures mediating adherence of $P$. aeruginosa to buccal cells (Woods et al., 1980b), tracheal cells (Doig et al., 1988) and human respiratory mucus (Ramphal et al., 1987), whereas results of other studies conflict with this suggestion (Marcus and Baker, 1985; Hata and Fick, 1987).

$P$. aeruginosa has been shown to agglutinate red blood cells by two different mechanisms-via the production of two distinct lectins (Gilboa-Garber, 1972) and via hydrophobic interaction between a surface haemagglutinin and the erythrocyte membranes (Glick et al., 1987). For several gramnegative bacteria, haemagglutinating activity is well correlated with adherence to epithelial cells (Dugoid and Old, 1980). Nevertheless, the role of these mechanisms on adherence of $P$. aeruginosa to the respiratory epithelium has never been investigated.

The present study was undertaken to evaluate whether HLE enhances adherence of $P$. aeruginosa to the respiratory mucosa and to determine the role of the different $P$. aeruginosa adhesins in adherence to the HLE-treated epithelium. In so far as HLEinduced mucus hypersecretion was expected to favour adherence of $P$. aeruginosa, an experimental model which allows mucus preservation-the frog palate mucosa (Plotkowski et al., 1989a)-was used throughout this study.

\section{Materials and methods}

\section{Bacteria}

$P$. aeruginosa isolates $8 \mathrm{M}, 13 \mathrm{M}, 14 \mathrm{M}$ and $24 \mathrm{M}$ were mucoid (M) strains collected from expectorated sputum samples from $\mathrm{CF}$ patients. Isolates $25 \mathrm{NM}, 27 \mathrm{NM}$, $144 \mathrm{NM}$ and $167 \mathrm{NM}$ were clinical non-mucoid (NM) strains from the same group of patients. The organisms were maintained in $1-\mathrm{ml}$ volumes of glycerol $20 \% \mathrm{v} / \mathrm{v}$ in Trypticase Soy Broth (TSB) and stored at $-20^{\circ} \mathrm{C}$.

\section{Adherence system}

A tissue-culture system simulating the air-liquid interphase in which respiratory epithelial cells are found in vivo was used throughout this study. Briefly, a strip of frog palate mucosa (FPM) on a membrane filter (Millipore SA; pore size $0.45 \mu \mathrm{m}$; diameter $13 \mathrm{~mm}$ ) was obtained as previously described (Plotkowski et al., 1989). The lower parts of Swinnex filters (Millipore SA; diameter $13 \mathrm{~mm}$ ) were sealed and filled, up to the railing, with Minimal Essential Medium (MEM) containing N-2-hydroxyethyl piperazine- $\mathrm{N}^{\prime}-2$-ethanesulphonic acid $1 \% \mathrm{w} / \mathrm{v}$ (MEMHEPES). The membrane filters covered by the FPM were placed over the filter railing and soaked with the underlying culture medium, in order to provide the necessary nutrients for the basement side of the mucosa. Thereafter, the two parts of the filters were screwed together and the epithelial surface of the FPM was ready to be submitted to different treatments.

\section{FPM treatment by human leucocyte elastase}

HLE was isolated and purified from purulent expectorated sputum (Martodam et al., 1979) and stored at $-20^{\circ} \mathrm{C}$ until used. For analysing the response of the FPM to the leucocyte protease, $100 \mu$ l of HLE $250 \mu \mathrm{g} / \mathrm{ml}$ in MEM-HEPES was introduced through the upper hole of the Swinnex filters and deposited over the epithelial surface of nine different FPM preparations. These were incubated in triplicate at $37^{\circ} \mathrm{C}$ for 1,2 and $4 \mathrm{~h}$. Afterwards, the filters were opened, the FPM preparations were rinsed with $0.1 \mathrm{M}$ phosphate-buffered saline, pH 7.2 (PBS) and examined by scanning electronmicroscopy (SEM). Control FPM preparations were treated with $100 \mu \mathrm{l}$ of MEM-HEPES, under the same conditions.

\section{$P$. aeruginosa adherence to HLE-treated FPM}

A 1-ml sample of each bacterial strain was thawed and inoculated into $10 \mathrm{ml}$ of TSB, and incubated for $18 \mathrm{~h}$ at $28^{\circ} \mathrm{C}$. The temperature of $28^{\circ} \mathrm{C}$ rather than $37^{\circ} \mathrm{C}$ was chosen because it favours internal lectin and fimbriae 
production (Fuerst and Hayward, 1969; Gilboa-Garber, 1972) and is closer to the environmental temperature than is $37^{\circ} \mathrm{C}$. Labelling of $P$. aeruginosa with ${ }^{99 \mathrm{~m}}$ Technetium $\left({ }^{99 \mathrm{~m}} \mathrm{Tc}\right)$ was performed as previously described (Plotkowski et al., 1987) and micro-organisms were suspended in MEM-HEPES at a concentration of $10^{9} \mathrm{cfu} / \mathrm{ml}$.

In each assay, part of the final bacterial suspension was centrifuged at $2000 \mathrm{~g}$ for $30 \mathrm{~min}$ and the supernate was filtered on to a $0.22-\mu \mathrm{m}$ pore size Millipore membrane. The counts of $100 \mu \mathrm{l}$ of this supernate and of an equal volume of the ${ }^{99 \mathrm{~m}}$ Tc-labelled $P$. aeruginosa suspension were determined in a scintillation counter with a sodium-iodide-thallium crystal. The ${ }^{99 \mathrm{~m}} \mathrm{Tc}$ counting was also related to the number of $\mathrm{cfu} / \mathrm{ml}$ determined by agar plate culture of the radiolabelled bacterial suspension.

To evaluate whether HLE enhances $P$. aeruginosa adherence to the respiratory epithelium, $100 \mu \mathrm{l}$ of the ${ }^{99 \mathrm{~m}} \mathrm{Tc}$-labelled suspension was introduced through the upper hole of the FPM-containing Swinnex filters and deposited over five FPM preparations treated with HLE solution for $4 \mathrm{~h}$ at $37^{\circ} \mathrm{C}$, as described above, as well as over five MEM-HEPES treated FPM preparations (controls). Even though $37^{\circ} \mathrm{C}$ is not the optimal temperature for the maintenance of FPM, it was chosen because it is the temperature at which bacteria meet human tissues. After incubation for $1 \mathrm{~h}$ at $37^{\circ} \mathrm{C}$, the filters were opened and the FPM preparations were rinsed with PBS, detached from the membrane filters and placed in vials to be counted in the scintillation counter. To eliminate the interference of changes in the specific activity of the $P$. aeruginosa suspension in different assays, the results were expressed according to the formula :

Percentage of associated $\mathrm{dpm}=$

counted $\mathrm{dpm}$
$\begin{aligned} & P \text {. aeruginosa } \text { suspension } \mathrm{dpm}- \\ & P . \text { aeruginosa } \text { filtered supernate } \mathrm{dpm}\end{aligned}$

\section{Scanning electronmicroscopy}

SEM was used for analysing the reaction of the FPM preparations incubated with HLE for different periods, as well as for determining to which components of the HLE-treated FPM the bacteria had adhered. The FPM preparations were fixed in glutaraldehyde $2.5 \% \mathrm{w} / \mathrm{v}$ in PBS overnight at $4{ }^{\circ} \mathrm{C}$, dehydrated in graded concentrations of ethanol, critical point dried, coated with gold palladium and examined with a Jeol JSM 25 or a SiemensAutoscan ETEC scanning electronmicroscope.

\section{Detection of fimbriae}

Bacteria were grown in TSB for $20 \mathrm{~h}$ at $28^{\circ} \mathrm{C}$. A drop of the bacterial cultures was placed on collodion-coated nickel grids and dried at $56^{\circ} \mathrm{C}$. The grids were rinsed with distilled water, stained with uranyl acetate $5 \% \mathrm{w} / \mathrm{v}$ for $3 \mathrm{~min}$ and examined with a Jeol $200 \mathrm{CX}$ transmission electronmicroscope.

\section{Determination of internal lectin haemagglutinating activity}

To improve the detection of internal lectins, bacteria were grown in Nutrient Broth, without glucose, with shaking at $28^{\circ} \mathrm{C}$ for 3 days. Choline chloride solution was added each day to the growth media at a final concentration of $0.2 \% \mathrm{w} / \mathrm{v}$. Cells were harvested, washed three times and resuspended in PBS to a final concentration of $(2-4) \times 10^{9} \mathrm{cfu} / \mathrm{ml}$. They were disrupted by an ultrasonic vibrator at $20 \mathrm{KHz}$ for $1 \mathrm{~h}$ (Gilboa-Garber, 1972). The supernatant fluids obtained by centrifugation at $30000 \mathrm{~g}$ at $4^{\circ} \mathrm{C}$ for $15 \mathrm{~min}$ were filtered through Millipore membranes (pore size $0.22 \mu \mathrm{m}$ ) and the protein concentration was determined to gauge bacterial cell disruption.

Neuraminidase-treated human blood group A erythrocytes were prepared by incubating, for $30 \mathrm{~min}$ at $37^{\circ} \mathrm{C}$, an erythrocyte suspension $15 \% \mathrm{v} / \mathrm{v}$ with a Clostridium perfringens neuraminidase solution (Sigma) at a final enzyme concentration of $0.2 \mathrm{U} / \mathrm{ml}$ in PBS, $\mathrm{pH} \mathrm{6.0.} \mathrm{The}$ enzyme-treated cells were washed in PBS and $100 \mu \mathrm{l}$ of an erythrocyte suspension $0.5 \% \mathrm{v} / \mathrm{v}$ were added to $100 \mu \mathrm{l}$ of serial two-fold dilutions of each $P$. aeruginosa cell-free extract. Titres were expressed as the highest dilution that showed complete agglutination of the erythrocytes. This haemagglutination test has been shown to detect both types (PAI and PAII) of $P$. aeruginosa lectins (GilboaGarber, 1986).

\section{Determination of surface haemagglutinating activity ( $S H A$ )}

Bacteria were grown in Trypticase Soy Agar containing choline chloride $1.4 \% \mathrm{w} / \mathrm{v}$ for $20 \mathrm{~h}$ at $28^{\circ} \mathrm{C}$, resuspended in PBS containing $1 \mathrm{mM} \mathrm{MgCl}_{2}$ (PBS-Mg) and centrifuged at $2000 \mathrm{~g}$ for $10 \mathrm{~min}$. The cell pellets were washed three times and suspended to a final concentration of $10 \% \mathrm{v} / \mathrm{v}$ in PBS-Mg containing cysteine $0.1 \% \mathrm{w} / \mathrm{v}$ (Glick et al., 1987). Papain-treated human blood group A erythrocytes were prepared by incubating 9 volumes of an erythrocyte $5 \% \mathrm{v} / \mathrm{v}$ suspension with 1 volume of papain $1 \% \mathrm{w} / \mathrm{v}$ (Crude preparation; Sigma) in cysteine $0.1 \% \mathrm{w} / \mathrm{v}$ at $37^{\circ} \mathrm{C}$, for $30 \mathrm{~min}$. The SHA assay was performed by adding $50 \mu \mathrm{l}$ of a papain-treated erythrocyte $5 \% \mathrm{v} / \mathrm{v}$ suspension to $200 \mu \mathrm{l}$ of serial two-fold dilutions of each $P$. aeruginosa suspension obtained as described above.

\section{Statistical analysis}

Student's $t$ test was used to determine whether the differences between $P$. aeruginosa adherence to HLEtreated and control FPM were statistically significant $(\mathrm{p}<0.05)$.

\section{Results}

\section{Electronmicroscopy}

Fig. 1a shows the control epithelium and fig. 1b the normal structure of cilia. The FPM treated with 

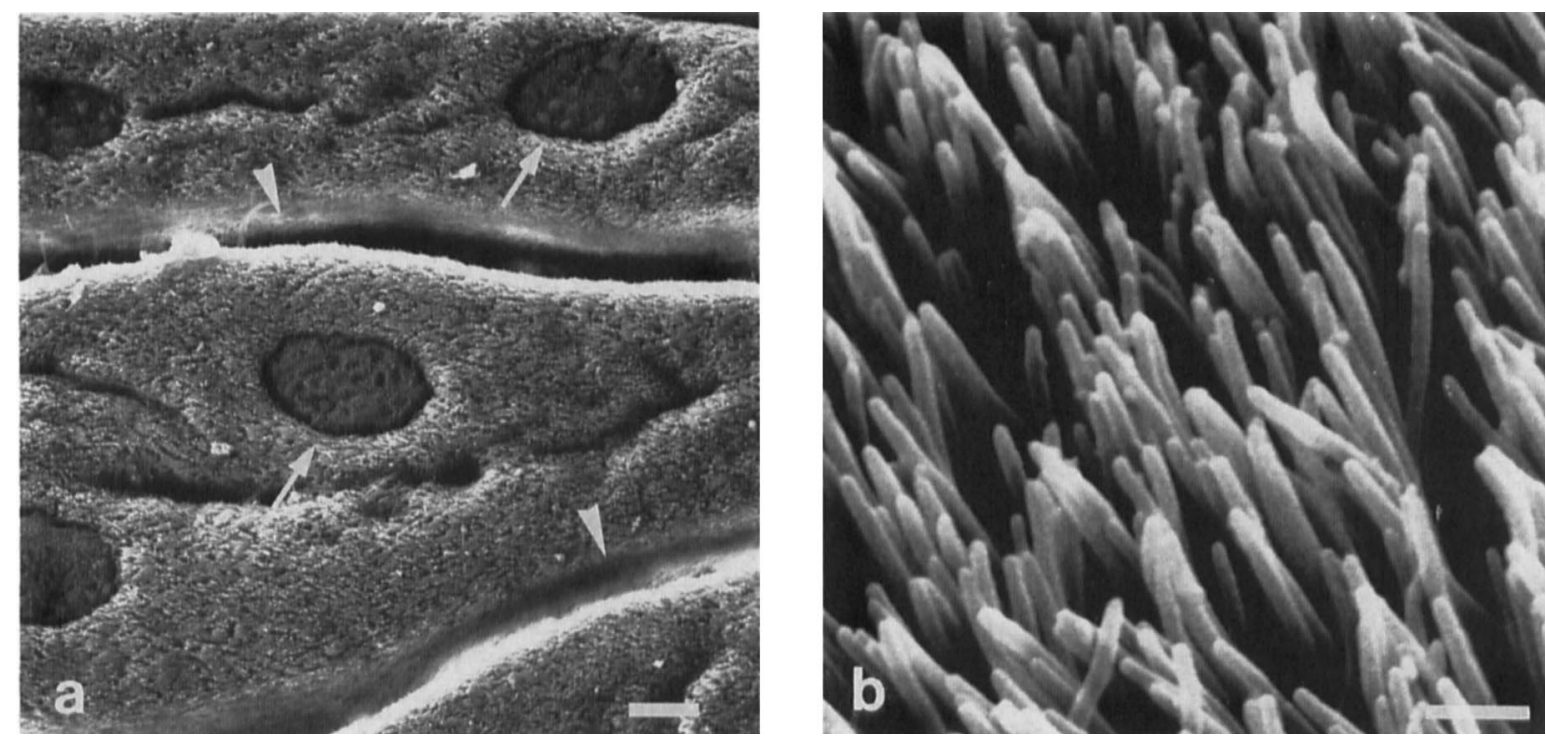

Fig. 1. SEM of control frog palate mucosa: (a) epithelium is covered by ciliated cells-note the presence of patches of sensory cells (arrows) and epithelial folding (arrowheads); (b) higher magnification showing normal structure of cilia. Bars $=50$ and $1 \mu \mathrm{m}$ respectively.

HLE for $1 \mathrm{~h}$ showed a mild hypersecretion of mucus but the ultrastructure of the epithelium was preserved (fig. 2a). After HLE treatment for $2 \mathrm{~h}$, an abundant outpouring of mucus was noted (fig. 2b) and the tips of the cilia were severely damaged (fig. 2c). After $4 \mathrm{~h}$, a marked mucus hypersecretion was accompanied by exfoliation of the epithelial cells with exposure of the submucosal underlying connective tissue (fig. 2d). In control FPM, only a few $P$. aeruginosa cells were seen attached to remaining patches of mucus (fig. 3). Bacteria rarely adhered directly to uninjured epithelium (not shown). In contrast, the HLE-treated FPM exposed to $P$. aeruginosa suspension showed an intense bacterial adherence to both recently secreted granules of mucus and to the exposed submucosal underlying connective tissue (fig. $4 a, b$ ).

\section{$P$. aeruginosa adherence to HLE-treated FPM}

The adherence of ${ }^{99 \mathrm{~m}} \mathrm{Tc}$-labelled bacteria to HLE-treated FPM was not uniform among the different $P$. aeruginosa strains studied. Although the percentage of radioactivity associated with the enzyme-treated mucosa was higher than that associated with control FPM in 7 of 8 cases, only strains $8 \mathrm{M}, 24 \mathrm{M}$ and $25 \mathrm{NM}$ adhered significantly more to HLE-treated than to control FPM (table I). The presence of the mucoid exopolysaccharide did not appear to be a significant factor influencing
$P$. aeruginosa adherence to the HLE-treated epithelium.

\section{Role of the different $P$. aeruginosa adhesins in} adherence to HLE-treated FPM

By transmission electronmicroscopy, it was demonstrated that all $P$. aeruginosa strains tested exhibited fimbriae. No differences in the number of fimbriae per bacterium or in the percentage of

Table I. Adherence of $P$. aeruginosa to HLE-treated or control FPM

\begin{tabular}{|c|c|c|c|}
\hline \multirow{2}{*}{$\begin{array}{l}P . \text { aeruginosa } \\
\text { strain }\end{array}$} & \multicolumn{2}{|c|}{${ }^{*}$ Adherence to FPM } & \multirow[b]{2}{*}{$\mathrm{p}$ value } \\
\hline & HLE-treated & Control & \\
\hline $8 \mathrm{M}$ & $19 \cdot 4(3 \cdot 8)$ & $8 \cdot 5(4 \cdot 0)$ & $<0.01$ \\
\hline $13 \mathrm{M}$ & $6.5(2.4)$ & $9 \cdot 7(7 \cdot 2)$ & NS \\
\hline $14 \mathrm{M}$ & $16 \cdot 1(8 \cdot 3)$ & $10 \cdot 5(8 \cdot 3)$ & NS \\
\hline $24 \mathrm{M}$ & $11 \cdot 5(3 \cdot 2)$ & $5 \cdot 0(2 \cdot 4)$ & $<0.01$ \\
\hline $25 \mathrm{NM}$ & $9.0(1.7)$ & $6.9(1.5)$ & $<0.01$ \\
\hline $27 \mathrm{NM}$ & $9 \cdot 5(11 \cdot 8)$ & $6 \cdot 4(4 \cdot 2)$ & NS \\
\hline 144 NM & $16 \cdot 3(6 \cdot 4)$ & $9 \cdot 7(4 \cdot 0)$ & NS \\
\hline $167 \mathrm{NM}$ & $11 \cdot 0(4 \cdot 8)$ & $7 \cdot 1(3 \cdot 0)$ & NS \\
\hline
\end{tabular}

$\mathbf{M}=$ mucoid $; \mathbf{N M}=$ non mucoid.

$\mathrm{NS}=$ not significant.

*Adherence is expressed as the mean percentage (and SD) of added radioactivity (radiolabelled bacteria) remaining on the mucosa. 

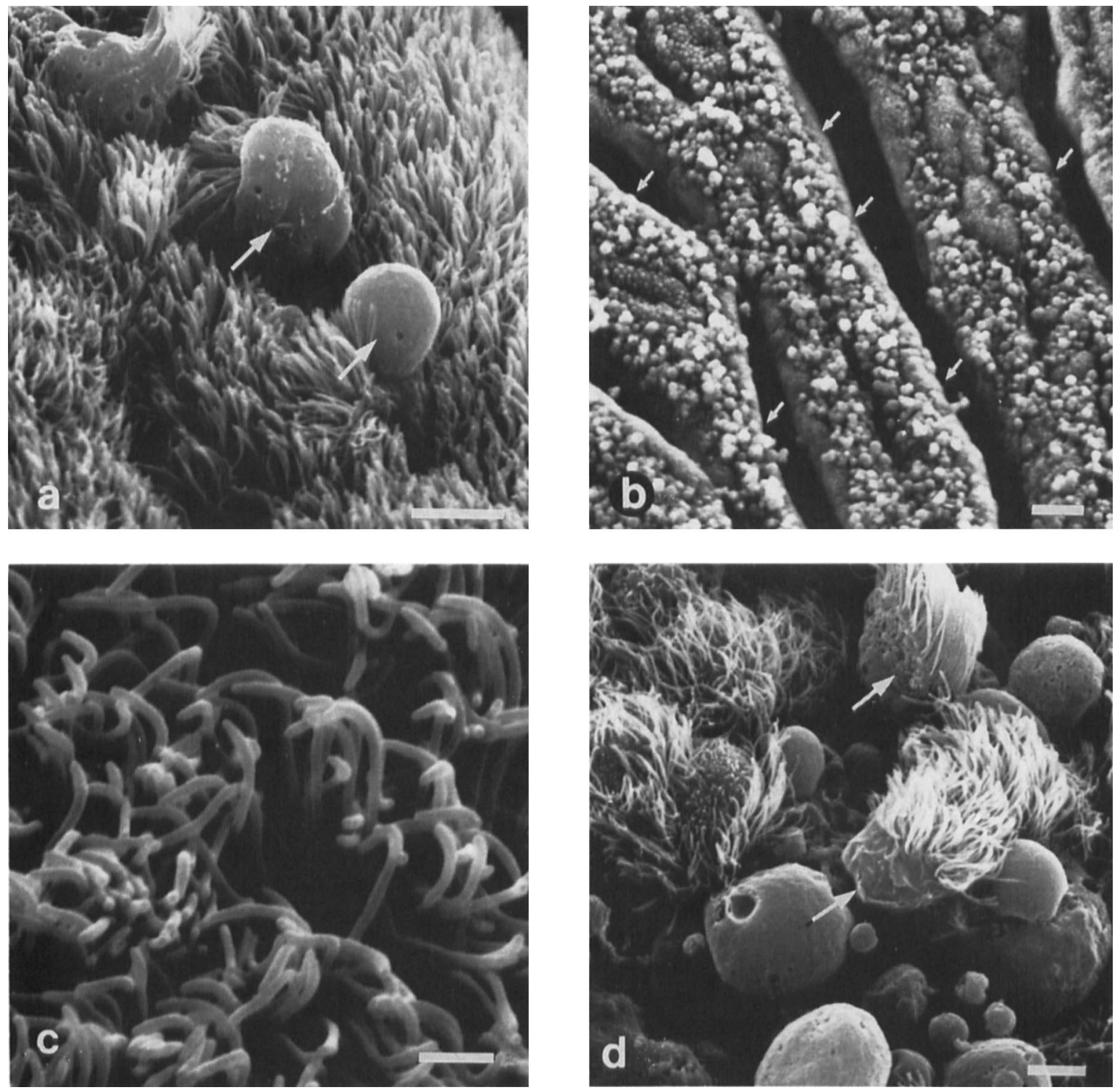

Fig. 2. SEM of frog palate mucosa treated with human leucocyte elastase: (a) for $1 \mathrm{~h}$-note the mild secretion of mucus granules (arrows); (b) and (c) for $2 \mathrm{~h}$-note the abundant outpouring of mucus granules (arrows) and the tips of the cilia severely damaged; (d) for $4 \mathrm{~h}$-note the desquamation of the epithelial cells (arrows). Bars $=10,50,1$ and $5 \mu \mathrm{m}$, respectively.

fimbriate cells could be determined between strains adherent or non-adherent to HLE-treated FPM. Table II presents the haemagglutination titres obtained with the different $P$. aeruginosa suspensions or cell-free extracts. No relationship was found between the level of the bacterial SHA and the internal lectin, between the internal lectin titre and the total protein concentration of the cell-free extract nor between the SHA and the adherence to HLE-treated FPM. In contrast, $P$. aeruginosa exhibiting higher internal lectin titres adhered significantly better to HLE-treated mucosa than to control untreated FPM.

\section{Discussion}

The ciliary clearance of mucus-entrapped microorganisms represents a major anti-infectious defence mechanism of the airways mucosa. Therefore, any factor compromising the transport of tracheo- 


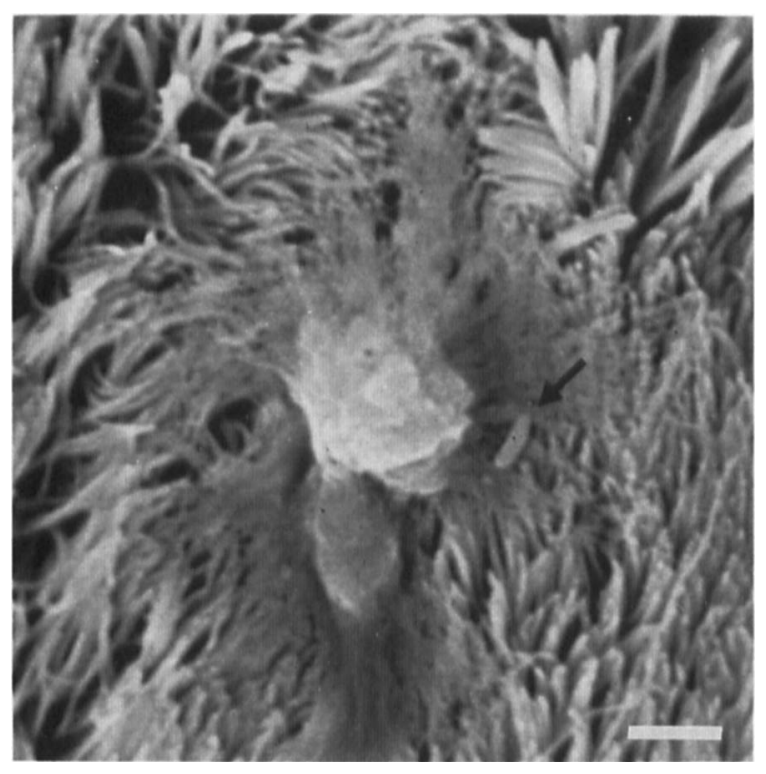

Fig. 3. SEM of control frog palate mucosa showing rare bacteria adhered to mucus (arrow). Bar $=2 \cdot 5 \mu \mathrm{m}$.

bronchial secretions, such as mucus hypersecretion, abnormalities of mucus rheological properties or ciliary damage (Greenstone and Cole, 1985) favours the multiplication of the micro-organisms attached to the mucus gel and infection of the underlying mucosa.

Most of the models proposed to study bacterial

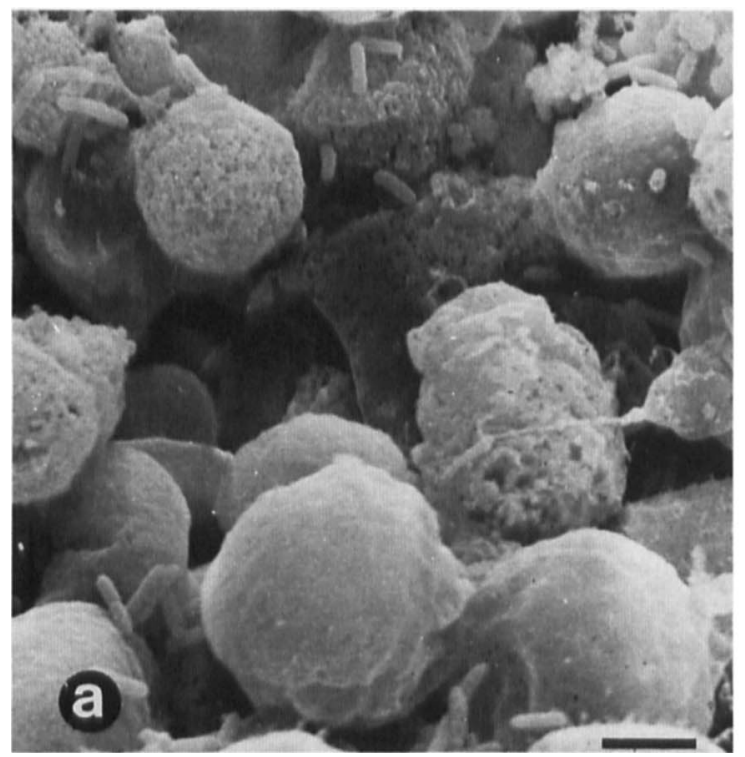

Table II. Relationship between $P$. aeruginosa internal lectin, surface haemagglutinating activity (SHA) and cell-free extract total protein concentration

\begin{tabular}{c|ccc}
\hline & Haemagglutination titre & $\begin{array}{c}\text { Cell-free extract } \\
\text { protein }\end{array}$ \\
\cline { 2 - 3 } $\begin{array}{c}\text { Bacterial } \\
\text { strain }\end{array}$ & SHA & $\begin{array}{c}\text { Internal } \\
\text { lectin }\end{array}$ & $\begin{array}{c}\text { concentration } \\
(\mu \mathrm{g} / \mathrm{ml})\end{array}$ \\
\hline $8 \mathrm{M}^{*}$ & 0 & $\geq 16$ & 140 \\
$13 \mathrm{M}^{14} \mathrm{M}$ & 32 & 0 & 440 \\
$24 \mathrm{M}^{*}$ & 4 & 0 & 280 \\
$25 \mathrm{NM}^{*}$ & 32 & $\geq 16$ & 670 \\
$27 \mathrm{NM}^{144} \mathrm{NM}$ & 64 & $\geq 16$ & 900 \\
$167 \mathrm{NM}$ & 64 & 2 & 180 \\
& ND & 0 & 260 \\
& 0 & 0 & 220 \\
\hline
\end{tabular}

$\mathbf{M}=$ mucoid $; \mathrm{NM}=$ non mucoid.

$\mathrm{ND}=$ not determined.

* $P$. aeruginosa strains for which adherence to HLE-treated mucosa was increased significantly (table I).

adherence to the respiratory mucosa differ from invivo conditions in that there is an absence of mucus. We have recently proposed that the frog palate mucosa (FPM) may be used as a model that allows the mucus coat to be preserved (Plotkowski et al., $1989 a$ ), in a system simulating the air-liquid interphase in which epithelial cells are found in vivo. The close similarity between the ultrastructure of FPM and the human tracheal mucosa (Puchelle et al., 1984) and the histochemistry of their mucus-

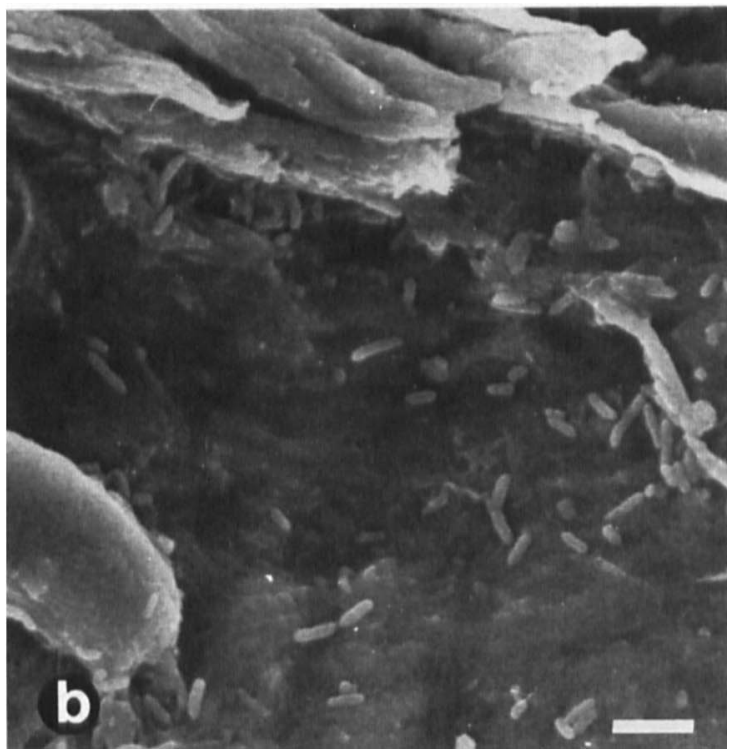

Fig. 4. SEM of frog palate mucosa treated with human leucocyte elastase exposed to $P$. aeruginosa cells showing bacteria attached to (a) secreted granules of mucus and (b) to desquamated mucosa. Bars $=2.5 \mu \mathrm{m}$. 
secreting cells (Plotkowski et al., 1989b) suggests that the FPM may be considered as a valuable model for studying bacterial adherence to the airways mucosa.

In the present study, we demonstrated, by SEM, that HLE, in the concentration range found in infected sputum samples from chronic bronchitis and CF patients (Stockley and Burnett, 1979; Goldstein and Döring, 1986), induces hypersecretion of mucus and that this represents an important factor promoting bacteria-host mucosa association.

Kim et al. (1987) have shown that, during the physiological discharge of the airways goblet cells, part of the secreted mucin is released into the exterior medium while another part remains tightly associated with the cell plasma membrane. This cell-surface mucin layer, and not the mucin packaged into secretory vesicles in the cell cytoplasm, constitutes the pool of mucin available to be released after HLE treatment. Its loss after the protease stimulus could induce a change in the reactivity of the apical surface of the goblet cells with gold-labelled lectins (Kim et al., 1987). These data, as well as those from Breuer et al. (1989) showing that HLE releases glycoconjugates from the surface of respiratory ciliated and secretory cells, suggest that, apart from inducing the impairment of the mucociliary transport, HLE may favour the adherence of bacteria to the airways mucosa by exposing membrane receptors usually masked by bound mucin.

In the present study, we also demonstrated that the prolonged exposure of the respiratory mucosa to HLE was followed by the desquamation of epithelial cells and exposure of the submucosal underyling connective tissues. The extracellular matrix represents an important pole of attraction for the adherence of $P$. aeruginosa. The observed bacterial adherence to HLE-injured mucosa is compatible with the opportunist character of $P$. aeruginosa, a micro-organism which infects tissues that have been injured by various means (Bodey et al., 1983). Adherence of $P$. aeruginosa to control mucosa was systematically low and usually associated with residual patches of mucus over the mucosa. The inability of $P$. aeruginosa to adhere to normal uninjured ciliated cells has been reported previously (Ramphal and Pyle, 1983). Also Baker and Marcus (1982) observed that, even 4-6 h after the infection of hamster tracheal explants with nonmucoid $P$. aeruginosa strains, few or no organisms were observed adhering to the tracheal epithelium. In contrast, several studies have shown the ability of $P$. aeruginosa to adhere to cilia of human tracheal cells (Niederman et al., 1983; Franklin et al., 1987;
Doig et al., 1988). This discrepancy was attributed to differences in susceptibility to the bacterial adhesins between human and animal tracheal cells (Franklin et al., 1987). However, all the studies showing adherence of $P$. aeruginosa to human airways cells have been performed with suspensions of cells collected by tracheal brushing. It has been shown that ciliated cells from quail oviduct at different stages of maturation present different membrane receptors (Chailley et al., 1982). Airways ciliated cells obtained by tracheal brushing correspond mainly to "pre-desquamating" cells. It may be that these cells, at a terminal differentiation stage, present receptors for microbial adhesins not found in mature airways cells. The finding of Lundberg et al. (1982), that bacterial adherence to desquamated nasal ciliated cells is much greater than adherence to the ciliated epithelium, seems to corroborate this hypothesis.

It has been suggested that the adherence of $P$. aeruginosa to eukaryotic cells, such as buccal, corneal, tracheal and phagocytic cells, is mediated by fimbriae (Woods et al., 1980b; Reichert et al., 1983; Paranchych et al., 1986). In our study, in as much as all the bacterial strains used were fimbriate, we could not attribute the observed difference to the capability of fimbriate bacteria to adhere to HLE-treated mucosa. Similarly, the presence of the mucoid exopolysaccharide could not explain the differences in bacterial adhesion.

Many microbial species adhere to and agglutinate red blood cells in a lectin-mediated phenomenon. The recent interest in microbial lectins is due to evidence that many of them play a crucial role in mediating adherence to surfaces colonised by micro-organisms (Uhlenbruck, 1987). Indeed, microbial lectins are now considered as determinants of virulence in both animal and plant infections (Sharon, 1987). Besides the lectin-mediated agglutination of erythrocytes, bacterial lipids or basic proteins may act as haemagglutinins (Mirelman and Ofek, 1986). For instance, $P$. aeruginosa surface haemagglutinating activity (SHA) depends on hydrophobic interaction between the bacterial and the eukaryotic cells (Glick et al., 1987). In the present study, no correlation could be found between SHA of $P$. aeruginosa and adherence to HLE-treated respiratory epithelium. Similarly, SHA could not be correlated with adherence to human buccal cells (Glick et al., 1987).

Besides possessing SHA, $P$. aeruginos $a$ have been shown to produce two distinct lectins, differing in their carbohydrate-binding specificity: PA-I binds D-galactose and its derivatives, whereas PA-II binds L-fucose, D-mannose and L-galactose (Gilboa- 
Garber, 1972). Most of the lectin activity is distributed inside the bacterial cell (Gilboa-Garber, 1986) but it is released promptly in the extracellular medium after bacterial disruption.

Marcus et al. (1989) have shown that the adherence of $P$. aeruginosa to tracheal epithelium was greatly increased in the presence of galactose- and $\mathrm{N}$-acetyl galactosamine-specific lectins. Since lectins present several sugar binding sites, they may act as a bridge between bacterial and host-cell polysaccharides. Similarly, it is possible that $P$. aeruginosa lectins, released in vivo during bacterial disruption by local host defence mechanisms, may also be necessary for binding of $P$. aeruginosa to host mucosa.

The production of $P$. aeruginosa lectins in vitro is greatly stimulated by the addition of choline to the culture medium (Gilboa-Garber, 1972). Under conditions of phosphate limitation, $P$. aeruginosa elaborates phospholipase $\mathrm{C}$ which catalyses the hydrolysis of phosphatidylcholine, yielding phosphorylcholine (Liu, 1979). In addition, an ordinary phosphatase that splits inorganic phosphate from phosphorylcholine is produced. The possibility that free choline may be found in the respiratory secretions of $C F$ patients, as a result of the degradation of phosphatidylcholine, the major lung

\section{REFERENCES}

Baker N R, Marcus H 1982 Adherence of clinical isolates of Pseudomonas aeruginosa to hamster tracheal epithelium in vitro. Current Microbiology 7: 35-40.

Bodey G P, Bolivar R, Fainstein V, Jadeja L 1983 Infections caused by Pseudomonas aeruginosa. Reviews of Infectious Diseases 5: 279-313.

Breuer R, Christensen T G, Niles R M, Stone P J, Snider G L 1989 Human neutrophil elastase causes glycoconjugate release from the epithelial cell surface of hamster trachea in organ culture. American Review of Respiratory Disease 139: 779-782.

Chailley B, Boisvieux-Ulrich E, Sandoz D 1982 Ciliary membrane events during ciliogenesis of the quail oviduct. Biology of the Cell 46: 51-64.

Cohen A B, Rossi M 1983 Neutrophils in normal lungs. American Review of Respiratory Disease 127: S3-S9.

Doig P, Smith N R, Todd T, Irvin R T 1987 Characterization of the binding of Pseudomonas aeruginosa alginate to human epithelial cells. Infection and Immunity 55: 1517-1522.

Doig P et al. 1988 Role of pili in adhesion of Pseudomonas aeruginosa to human respiratory epithelial cells. Infection and Immunity 56: 1641-1646.

Duguid J P, Old D C 1980 Adhesive properties of Enterobacteriaceae. In : Beachey E H (ed) Bacterial adherence. Chapman and Hall, London, pp 187-217.

Franklin A L, Todd T, Gurman G, Black D, Mankinen-Irvin P M, Irvin R T 1987 Adherence of Pseudomonas aeruginosa to cilia of human tracheal epithelial cells. Infection and Immunity 55: 1523-1525. surfactant, would support the attractive hypothesis that $P$. aeruginosa lectins may play a crucial role in their adherence to airways mucosa in vivo.

Gilboa-Garber (1983) has found a close correlation between the lectin level inside $P$. aeruginosa cells and the ability of the bacteria to secrete cytotoxic factors such as protease, haemolysin and pyocyanin. If, as he proposed, the presence of internal lectin is crucial for the secretion of these toxins, their effect is not limited to the adherence phenomenon but should be also considered in relation to tissue damage.

It is evident from the foregoing data that further work is required to gain a clear understanding of the role of lectins in the virulence of $P$. aeruginosa in the respiratory tract. Nevertheless, it seems clear from the present results that during infection, and following inflammation, the leucocyte proteinase favours the persistence of $P$. aeruginosa infection by enhancing adherence to the airways mucosa.

We are grateful to M. A. Pereira da Silva, C. Fuchey and J. Lambert for excellent technical assistance, Dr. B. Foliguet for help with scanning electronmicroscopy and C. Champion for typing this manuscript. This work was supported by an INSERM-CNPq cooperation and by grant No. 40.24.10/86 from CNPq (Brazil).
Fuerst J A, Hayward A C 1969 Surface appendages similar to fimbriae (pili) on Pseudomonas species. Journal of General Microbiology 58: 227-237.

Gallin I 1984 Neutrophil specific granules: a fuse that ignites the inflammatory response. Clinical Research 67: 320-328.

Geddes D 1984 Progress in research on cystic fibrosis. Thorax 39: $721-725$

Gilboa-Garber N 1972 Purification and properties of hemagglutinin from Pseudomonas aeruginosa and its reaction with human blood cells. Biochimica et Biophysica Acta 273: 165173.

Gilboa-Garber N 1983 The biological functions of Pseudomonas aeruginosa lectins. In: Bog-Hansen TC, Spengler GA (eds) Lectins: biology, biochemistry, clinical biochemistry, vol III, Walter de Gruyter \& Co, Berlin, pp 495-502.

Gilboa-Garber N 1986 Lectins of Pseudomonas aeruginosa: properties, biological effects and applications. In: Mirelman D (ed) Microbial lectins and agglutinins: properties and biological activities. (Environmental and Applied Microbiology). John Wiley \& Sons, London, pp 255-269.

Glick J, Garber N, Shohet D 1987 Surface haemagglutinating activity of Pseudomonas aeruginosa. Microbios 50: 69-80.

Goldstein W, Döring G 1986 Lysosomal enzymes from polymorphonuclear leukocytes and proteinase inhibitors in patients with cystic fibrosis. American Review of Respiratory Disease 134: 49-56.

Greenstone M, Cole P J 1985 Ciliary function in healthy and disease. British Journal of Diseases of the Chest 79: 9-26.

Hata J S, Fick R B 1987 Cellular mechanisms of Pseudomonas aeruginosa adherence to canine tracheal epithelial cell 
monolayers. American Review of Respiratory Disease 135: A364.

Havemann K, Gramse M 1984 Physiology and pathophysiology of neutral proteinases of human granulocytes. In : Hörl W $\mathrm{H}$, Heidland A (eds) Proteases: potential role in health and disease. Advances in experimental medicine and biology, vol 167, Plenum Press, New York, London, pp 1-20.

Kim K C, Wasano K, Niles R M, Schuster J E, Stone P J, Brody J S 1987 Human neutrophil elastase releases cell surface mucins from primary cultures of hamster tracheal epithelial cells. Proceedings of the National Academy of Sciences of the USA 84: 9304-9308.

Liu P V 1979 Toxins of Pseudomonas aeruginosa. In: Doggett R $G$ (ed) Pseudomonas aeruginosa: Clinical manifestations of infection and current therapy. Academic Press Inc, NewYork, pp 63-87.

Lundberg C, Lönnroth J, Nord C E 1982 Adherence in the colonization of Streptococcus pneumoniae in the nasopharynx in children. Infection 10 : 63-66.

Marcus H, Baker N R 1985 Quantification of adherence of mucoid and non-mucoid Pseudomonas aeruginosa to hamster tracheal epithelium. Infection and Immunity 47: 723-729.

Marcus H, Austria A, Baker N R 1989 Adherence of Pseudomonas aeruginosa to tracheal epithelium. Infection and Immunity 57: 1050-1053.

Martodam R R, Baugh R J, Twumasi D Y, Liener I E 1979 A rapid procedure for the large scale purification of elastase and cathepsin $\mathrm{G}$ from human sputum. Preparative Biochemistry 9: 15-31.

McDonald J A, Baum B J, Rosenberg D M, Kelman J A, Brin S C, Crystal R G 1979 Destruction of a major extracellular adhesive glycoprotein (fibronectin) of human fibroblasts by neutral proteases from polymorphonuclear leukocyte granules. Laboratory Investigation 40: 350-357.

Mirelman D, Ofek I 1986 Introduction to microbial lectins and agglutinins. In: Mirelman D (ed) Microbial lectins and agglutinins: properties and biological activities (Environmental and Applied Microbiology) John Wiley \& Sons, London, pp 1-19.

Niederman M S, Rafferty T D, Sasaki C T, Merrill W W, Matthay R A, Reynolds H Y 1983 Comparison of bacterial adherence to ciliated and squamous epithelial cells obtained from the human respiratory tract. American Review of Respiratory Disease 127 : 85-90.

Ohlsson K, Olsson I 1977 The extracellular release of granulocyte collagenase and elastase during phagocytosis and inflammatory processes. Scandinavian Journal of Haematology 19 : $145-152$.

Paranchych W, Sastry P A, Volpel K, Loh B A, Speert D P 1986 Fimbriae (pili): molecular basis of Pseudomonas aeruginosa adherence. Clinical and Investigative Medicine 9: 113-118.

Pennington J E, Wolf S M, Puziss M 1979 Summary of a workshop on infections in patients with cystic fibrosis. Journal of Infectious Diseases 140 : 252-256.

Plotkowski M C, Beck G, Bernardo Filho M, Oliveria E F R, Hinnrasky J, Puchelle E 1987 Evaluation of ${ }^{99 \mathrm{~m}}$ Technetium labelling effect on Pseudomonas aeruginosa surface properties. Annales de l'Institut Pasteur Microbiologie 138: 415426.

Plotkowski M C, Beck G, Jacquot J, Puchelle E 1989a The frog palate mucosa as a model for studying bacterial adhesion to mucus-coated respiratory epithelium. Journal of Comparative Pathology 100: 37-46.

Plotkowski M C, Girod-Vaquez S, Hinnrasky J, Fuchey C, Ploton D, Puchelle E $1989 b$ Ultrastructural comparative distribution of carbohydrates in human tracheal and frog palate mucosa using neuraminidase and lectin-colloidal gold complexes. Journal of Submicroscopic Cytology and Pathology (in press)

Puchelle E, Petit A, Adnet J J 1984 Fine structure of the frog palate mucociliary epithelium. Journal of Submicroscopic Cytology 16: 273-282.

Ramphal R, Pyle M 1983 Adherence of mucoid and nonmucoid Pseudomonas aeruginosa to acid-injured tracheal epithelium. Infection and Immunity 41 : 345-351.

Ramphal R, Pier G B 1985 Role of Pseudomonas aeruginosa mucoid exopolysaccharide in adherence to tracheal cells. Infection and Immunity $47:$ 1-4.

Ramphal R, Guay C, Pier G B 1987 Pseudomonas aeruginosa adhesins for tracheobronchial mucin. Infection and Immunity 55: $600-603$.

Reichert R W, Das N E, Zam Z S 1983 Adherence properties of Pseudomonas pili to epithelial cells of the human cornea. Current Eye Research 2: 289-293.

Sharon N 1987 Bacterial lectins, cell-cell recognition and infectious disease. FEBS Letters 217: 145-157.

Smallman L A, Hill S L, Stockley R A 1984 Reduction of ciliary beat frequency in vitro by sputum from patients with bronchiectasis: a serine protease effect. Thorax 39: 663667.

Stockley R A, Burnett D 1979 Alpha-1-antitrypsin and leukocyte elastase in infected and noninfected sputum. American Review of Respiratory Disease 120: 1081-1086.

Sturgess J M 1981 Mucus secretion and clearance in the pathogenesis of cystic fibrosis. Monographs in Pediatrics 14: 60-74.

Suter S, Schaad U B, Roux L, Nydegger U E, Waldvogel F A 1984 Granulocyte neutral proteases and Pseudomonas elastase as possible causes of airway damage in patients with cystic fibrosis. Journal of Infectious Diseases 149: 523531.

Suter S, Schaad U B, Morgenthaler J J, Chevallier I, Schnebli H P 1988 Fibronectin-cleaving activity in bronchial secretions of patients with cystic fibrosis. Journal of Infectious Diseases 158: 89-100.

Uhlenbruck G 1987 Bacterial lectins: mediators of adhesion. Zentralblatt fur Bakteriologie, Mikrobiologie und Hygiene. Series A 263: 497-508.

Woods D E, Bass J A, Johanson W G, Strauss D C 1980a Role of adherence in the pathogenesis of Pseudomonas aeruginosa lung infection in cystic fibrosis patients. Infection and Immunity 30: 694-699.

Woods D E, Strauss D C, Johanson W G, Berry V K, Bass J A $1980 b$ Role of pili in adherence of Pseudomonas aeruginosa to mammalian buccal epithelial cells. Infection and Immunity 29: 1146-1151.

Woods D E, Strauss D C, Johanson W G, Bass J A 1983 Factors influencing the adherence of Pseudomonas aeruginosa to mammalian buccal epithelial cells. Reviews of Infectious Diseases 5 suppl 5 : S846-S851. 